\title{
Evolution of Antibiotic Consumption at Moulay Ismail Military Hospital in Meknes between 2016 and 1018
}

\author{
El Kartouti Abdeslam ${ }^{1 *}$, Larbi Amhajji ${ }^{2}$, My Ahmed Hachimi ${ }^{3}$ \\ ${ }^{1}$ Department of Hospitalary Pharmacist, Sidi Mohammed Ben Abdellah University in Fez, Morocco \\ ${ }^{2}$ Department of Trauma and Orthopedic, Sidi Mohammed Ben Abdellah University in Fez, Morocco \\ ${ }^{3}$ Department of Anesthésie-Intensive Care, Sidi Mohammed Ben Abdellah University in Fez, Morocco
}

\begin{abstract}
DOI: $10.36348 /$ sjmps.2020.v06i07.004 $\quad$ | Received: 28.06.2020 | Accepted: 06.07.2020 | Published: 21.07 .2020
*Corresponding author: El Kartouti Abdeslam
\end{abstract}

\section{Abstract}

Introduction: The rational use of antibiotics is a major concern due to the development of bacterial resistance and the emergence of multiresistant bacteria. The objective of this study is to evaluate the consumption of antibiotics within the HMMI for 3 years (2016 to 2018). Materials and Methods: This is a retrospective study of the consumption of antibiotics for 3 years (2016 to 2018), allowing the distribution of hospital services in 5 activity sectors; whereas the calculation of antibiotic consumption in DDJ / 1000JH made it possible to determine the overall consumption of all antibiotics of the HMMI in DDJ / 1000JH for the years 2016-2017-2018; to determine the consumption by antibiotic families of HMMI in DDJ / $1000 \mathrm{JH}$ for the years 2016-2017-2018; to determine the average consumption by antibiotic families and by activity sectors in DDJ / 1000JH. Results: The analysis of the overall consumption of all antibiotic families combined showed a consumption of 861.38 DDJ / 1000JH in 2017 and 700.97 DDJ / 1000JH in 2018. While the calculation of the percentage change between the years 2016 and 2018 revealed a decrease in the overall consumption of antibiotics by (-9.07\%). Analysis of consumption by families of antibiotics has shown that betalactamines are the most prescribed molecules with $77.39 \%$ or on average $(601.86 \mathrm{DDJ} / 1000 \mathrm{JH})$; monitoring of fluoroquinolones with $7.21 \%$ or on average (56.08 DDJ / 1000JH); monitoring of aminoglycosides with $6.44 \%$ or on average (50.12 DDJ / 1000JH). Analysis of the overall antibiotic consumption by sector of activity has shown that the resuscitation sector is the sector most prescribing antibiotics of all families, with an average of 1345.61 DDJ / $1000 \mathrm{JH}$. Discussion: The results of our work showed high consumption, explained either by an adapted prescription policy or overconsumption by inappropriate prescriptions. Various surveys show that 20 to $50 \%$ of prescriptions for antibiotics are inappropriate in hospitals. Conclusion: The link between the use of antibiotics and the emergence of bacterial resistance is clear The present retrospective study was an important assessment. Which must be supplemented by prospective studies evaluating the quality of prescription at the level of the services most consuming antibiotics.

Keywords: Bacterial resistance, Consumption of antibiotics, Definite daily dose, Nominal prescriptions.

\footnotetext{
Copyright @ 2020: This is an open-access article distributed under the terms of the Creative Commons Attribution license which permits unrestricted use, distribution, and reproduction in any medium for non-commercial use (NonCommercial, or CC-BY-NC) provided the original author and source are credited.
}

\section{INTRODUCTION}

The discovery and development of antibiotics was a major advance that revolutionized the history of medicine. Indeed, these new drugs have made it possible to improve the prognosis of bacterial infections that were difficult to heal until then; associated with the development of public hygiene measures and vaccination, they have enabled a reduction in mortality due to infectious diseases. Indeed, only a few years after the introduction of penicillin in therapy, it was found the emergence of strains resistant to this antibiotic. Thus, for each new antibiotic introduced in therapy, the discovery of bacterial strains resistant to this antibiotic is frequently reported, a few years after its introduction. Given the absence of antibiotic prescription protocols in our hospital structure and as it is commonly recognized that bad habits in terms of prescriptions favor the emergence of resistance, we found it necessary to carry out an evaluation of the evolution of the consumption of antibiotics that were prescribed during 2016-2017-2018, the aim of which is to propose corrective measures, which will probably help limit the incidence of multi-resistant bacteria and reduce the cost of the antibiotics used and raise awareness prescribers with ecological consequences resulting from the act of prescription. 


\section{Material ANd Methods}

The study was based on data from the pharmaceutical management program, namely the sheets issued by products, the sheets released by antibiotic departments for the years 2016-2017-2018.

\section{Type, Place and Period of Study}

This is firstly a descriptive, retrospective study of the evolution of antibiotic consumption at the HMMI level; the statistical calculation of DDJ / 1000JH was performed on Excel 2010. The study s 'takes place at the hospital pharmacy of the My Ismail military hospital in Meknes. This retrospective and descriptive study of the evolution of antibiotic consumption spanned a period of 3 years (2016-20172018).

\section{Methodology}

The methodology consisted in determining the hospital sectors prescribing antibiotics and in listing the antibiotics registered in the therapeutic booklet of the hospital and prescribed, in choosing the indicators to carry out this evaluation thus, the two indicators chosen are the defined daily dose (DDD) and Hospitalization Days (DH); these are two benchmarks used for antibiotics; their combination makes it possible to calculate the number of Daily Defined Doses per 1000 days of hospitalization (nb of DDD / 1000DH).

DDJ is a WHO defined unit used for comparisons of drug use between different populations. It is a daily reference dosage, determined by international experts, which is supposed to represent the usual dosage for an adult of $70 \mathrm{Kg}$ in the main indication of an active ingredient. To calculate the number of DDD (days of treatment at the reference dosage), you need the total quantity in grams of the drug concerned and divide this quantity by the value of the DDD in gram for this same drug. It should also be specified that in the case of associated forms of active principles, it will then be necessary to dissociate these 2 active principles and to take into account the 2 respective DDDs.

The days of hospitalization constitute the denominator to be taken into account, which corresponds to the number of days billed by the entry office or the equivalent structure, and also take into account day hospitalizations and week hospitalization. The result will be expressed in DDD / 1000 days of hospitalization by multiplying the ratio between the number of DDD of an antibiotic for the year studied / number of days of hospitalization for the year studied, by 1000 . This new indicator is not an indicator of dosage recommendations or good therapeutic indications but it allows a comparison by molecules and families of antibiotics taking into account a standard dosage (DDD). It includes, in addition to the number of drugs consumed, the number of beds and the number of hospital days per care unit. This indicator makes it easier for healthcare professionals to interpret, by linking the consumption of antibiotics to the number of patients and hospital days. In addition, this indicator makes it possible to carry out annual monitoring of the consumption of antibiotics in the various care services of the same establishment or between health establishments.

\section{Data Collection}

Consumption of antibiotics in quantity of common dispensing units dispensed for each presentation of an antibiotic, ie the number of tablets, sachets, ampoules, bottles of oral solution ... for each pharmaceutical form marketed.

The following were excluded: All anti-tuberculosis drugs.

The quantities entered in the Excel 2010 file were converted into the number of defined daily doses (DDJ) for each antibiotic, then reported to the activity in order to express the consumption indicator in number of DDJ per 1000 days of hospitalization (DD) ) as recommended. The DDJ values used were those defined by the World Health Organization (WHO) and in force on January 1, 2010. For products containing two antibiotics; the DDJs of the two compounds were counted and assigned to the corresponding family of antibiotics. The study of the analytical accounting of each antibiotic during the year 2015, taking into account their hospital purchase prices, their prescribed daily dosages and their treatment durations according to the pathologies supported by hospital services. This analysis made it possible to determine the most expensive antibiotics, to calculate the cost of daily treatment with antibiotics and to assess the overall cost of treatment for certain services. All of the data collected was processed using "Excel 2010".

\section{Analysis of the Results}

The distribution of hospital services by activity sector; this breakdown made it possible to distinguish 5 sectors: medicine sector, surgery sector, resuscitation sector, gynecology sector and psychiatry sector.

The calculation of antibiotic consumption in DDD / 1000DH allowed

- To determine the overall consumption of all antibiotics of the HMMI in DDD / $1000 \mathrm{DH}$ for the years 2016-2017-2018.

- Determine the consumption by antibiotic families of HMMI in DDD / $1000 \mathrm{DH}$ for the years 2016-2017-2018.

- Determine the average consumption by antibiotic families and by activity sectors in DDD / 1000DH. 


\section{RESULTS}

The distribution of hospital services by activity sector
This distribution of hospital services into activity sectors made it possible to distinguish 5 sectors (Table-1).

Table-1: Services and business sectors

\begin{tabular}{|l|l|}
\hline Sectors of activity & Corresponding services \\
\hline Medicine & $\begin{array}{l}\text { Cardiology, dermatology, endocrinology, gastroenterology, neurology, pneumology, internal } \\
\text { medicine, rheumatology, oncology, hematology }\end{array}$ \\
\hline surgery & $\begin{array}{l}\text { Central operating room surgery, visceral surgery, trauma and orthopedic surgery, vascular surgery, } \\
\text { thoracic surgery, maxillofacial surgery, plastic surgery, ophthalmology, ORL, neurosurgery }\end{array}$ \\
\hline Resuscitation & Resuscitation surgical and medical resuscitation \\
\hline gynecology & gynecology service \\
\hline Psychiatry & psychiatry service \\
\hline
\end{tabular}

The consumption of antibiotics in DDD / $1000 \mathrm{DH}$ Analysis of the overall consumption of all families of antibiotics combined:

Analysis of the overall consumption of all antibiotic families combined showed a consumption of
861.38 DDD / 1000DH in 2017 and 700.97 DDD / $1000 \mathrm{DH}$ in 2018. While the calculation of the percentage change between the years 2016 and 2018 revealed a decrease of the overall consumption of antibiotics by $(-9.07 \%)$ (Table-2).

Table-2: The overall consumption of all families of antibiotics combined

\begin{tabular}{|l|l|l|l|l|l|}
\hline Antibiotics & $\begin{array}{l}2016 \\
\text { DDD/1000DH }\end{array}$ & $\begin{array}{l}2017 \\
\text { DDD/1000DH }\end{array}$ & $\begin{array}{l}\text { 2018 } \\
\text { DDD/1000DH }\end{array}$ & $\begin{array}{l}\text { \% variation between } \\
2016 \text { and 2018 }\end{array}$ & $\begin{array}{l}\text { Average } \\
\text { consumption } \\
\text { DDD/1000DH }\end{array}$ \\
\hline $\begin{array}{l}\text { Overall consumption of } \\
\text { all antibiotics (excluding } \\
\text { anti-bacilli) }\end{array}$ & $\mathbf{7 7 0 , 9 2}$ & $\mathbf{8 6 1 , 3 9}$ & 700,97 & $-9.07 \%$ & 777,76 \\
\hline
\end{tabular}

\section{Analysis of consumption by families of antibiotics}

Analysis of consumption by families of antibiotics has shown that betalactamins are the most prescribed molecules with $77.39 \%$ or on average
(601.86 DDD/1000DH); monitoring of fluoroquinolons with $7.21 \%$ or on average $(56.08 \mathrm{DDD} / 1000 \mathrm{DH})$; monitoring of aminoglycosides with $6.44 \%$ or on average (50.12 DDD / 1000DH);... (Table-3).

Table-3: Consumption by families of antibiotics

\begin{tabular}{|c|c|c|c|c|c|c|}
\hline $\begin{array}{l}\text { ATC } \\
\text { CLASS }\end{array}$ & Designation & $\begin{array}{l}2016 \\
\text { DDD/1000DH }\end{array}$ & $\begin{array}{l}2017 \\
\text { DDD/1000DH }\end{array}$ & $\begin{array}{l}2018 \\
\text { DDD/1000DH }\end{array}$ & $\begin{array}{l}\text { Percentage } \\
\text { change between } \\
2016 \text { and } 2018\end{array}$ & $\begin{array}{l}\text { Average } \\
\text { consumption } \\
\text { DDD/1000DH } \\
\end{array}$ \\
\hline J01C & FLUCLOXACILLIN 1G INJ & 58,74 & 37,30 & 20,69 & $-64,77 \%$ & 38,91 \\
\hline J01C & FLUCLOXACILLIN 500 MG & 4,67 & 8,94 & 6,17 & $32,02 \%$ & 6,59 \\
\hline J01D & AMOXICILLIN 1 G CP & 71,55 & 56,65 & 22,34 & $-68,77 \%$ & 50,18 \\
\hline J01D & AMOXICILLIN 1 G INJ & 127,26 & $\mathbf{1 0 4 , 8 3}$ & 56,52 & $-55,58 \%$ & 96,21 \\
\hline J01D & $\begin{array}{l}\text { AMOXICILLIN + CLAVULANIC } \\
\text { Acid 1G INJ }\end{array}$ & 145,10 & 188,26 & 164,24 & $13,19 \%$ & 165,87 \\
\hline J01D & $\begin{array}{l}\text { AMOXICILLINE + CLAVULANIC } \\
\text { Acid 1G SACHET }\end{array}$ & 116,39 & 152,54 & 167,30 & $43,74 \%$ & 145,41 \\
\hline J01D & CEFALOTIN 1G INJ TYPE & 5,92 & 12,95 & 9,06 & $53,04 \%$ & $\mathbf{9 , 3 1}$ \\
\hline J01D & CEFUROXIM 750 MG INJ & 2,66 & 4,54 & 1,40 & $-47,36 \%$ & 2,86 \\
\hline J01DD & CEFTAZIDIM 1G INJ & 4,55 & 6,13 & 7,40 & $62,70 \%$ & 6,02 \\
\hline J01DD & CEFTRIAXON 1G INJ & 57,64 & 77,08 & 60,60 & $5,14 \%$ & 65,11 \\
\hline J01DH & $\begin{array}{l}\text { IMIPENEM + CILASTATINE } 500 \\
\text { MG INJ }\end{array}$ & 11,52 & 20,68 & 13,98 & $21,34 \%$ & 15,39 \\
\hline J01E & $\begin{array}{l}\text { SULFAMETHOXASOLE } \\
\text { TRIMETHOPRIME }\end{array}$ & $\mathbf{0}$ & $\mathbf{0}$ & $\mathbf{0}$ & $\mathbf{0}$ & $\mathbf{0 , 0 0}$ \\
\hline J01F & AZITHROMICINE 500 MG CP & 13,14 & 2,34 & 12,75 & $-3,01 \%$ & 9,41 \\
\hline J01G & GENTAMYCINE 160 MG INJ & 56,35 & 52,24 & 41,77 & $-25,86 \%$ & 50,12 \\
\hline J01M & CIPROFLOXACIN 200 MG INJ & 20,51 & 26,94 & 23,79 & $15,98 \%$ & 23,75 \\
\hline J01M & CIPROFLOXACIN 500 MG CP & 26,58 & 37,87 & 32,54 & $22,40 \%$ & 32,33 \\
\hline J04AB & RIFAMPICINE & $\mathbf{0}$ & $\mathbf{0}$ & $\mathbf{0}$ & $\mathbf{0}$ & $\mathbf{0 , 0 0}$ \\
\hline J01A & TETRACYCLINE & $\mathbf{0}$ & $\mathbf{0}$ & $\mathbf{0}$ & $\mathbf{0}$ & $\mathbf{0 , 0 0}$ \\
\hline J01X & COLIMYCINE 1 G INJ & 2,70 & $\mathbf{1 1 , 0 3}$ & 13,37 & $395,52 \%$ & $\mathbf{9 , 0 3}$ \\
\hline J01X & VANCOMICINE 500 MG INJ & 2,08 & 1,72 & 2,26 & $\mathbf{8 , 5 8 \%}$ & 2,02 \\
\hline J01X & METRONIDAZOL 500 MG INJ & 35,59 & 48,65 & 31,53 & $-11,40 \%$ & 38,59 \\
\hline P01AB & METRONIDAZOL 500 MG CP & 7,97 & 10,69 & 13,25 & $66,27 \%$ & 10,64 \\
\hline
\end{tabular}


El Kartouti Abdeslam et al; Saudi J Med Pharm Sci, July, 2020; 6(7): 499-506

Analysis of the overall consumption of antibiotics by sector of activity

Analysis of the overall consumption of antibiotics by sector of activity has shown that the resuscitation sector is the sector most prescribing antibiotics of all families, with an average of 1345.61 DDD/1000 DH; monitoring of the gynecology sector with an average of $1261.13 \mathrm{DDD} / 1000 \mathrm{DH}$; monitoring of the surgery sector with an average of 733.75 DDD/ 1000DH; ... (Table-4).

Table-4: Overall consumption of antibiotics by sector of activity

\begin{tabular}{|l|l|l|l|l|l|}
\hline Activity sectors & $\begin{array}{l}2016 \\
\text { DDD/1000DH }\end{array}$ & $\begin{array}{l}2017 \\
\text { DDD/1000DH }\end{array}$ & $\begin{array}{l}\mathbf{2 0 1 8} \\
\text { DDD/1000DH }\end{array}$ & $\begin{array}{l}\text { \% variation between } \\
2016 \text { and 2018 }\end{array}$ & $\begin{array}{l}\text { Average consumption } \\
\text { DDD/1000DH }\end{array}$ \\
\hline $\begin{array}{l}\text { Medicine sector (number } \\
\text { DDD / 1000DH) }\end{array}$ & $\mathbf{6 9 7 , 7 6}$ & $\mathbf{5 8 6 , 7 8}$ & $\mathbf{4 2 2 , 3 3}$ & $\mathbf{- 3 9 , 4 7 \%}$ & $\mathbf{5 6 8 , 9 6}$ \\
\hline $\begin{array}{l}\text { Surgery sector (number } \\
\text { DDD / 1000DH) }\end{array}$ & $\mathbf{7 7 5 , 9 5}$ & $\mathbf{8 1 9 , 9 6}$ & $\mathbf{6 0 5 , 3 3}$ & $\mathbf{- 2 1 , 9 9 \%}$ & $\mathbf{7 3 3 , 7 5}$ \\
\hline $\begin{array}{l}\text { Resuscitation sector } \\
\text { (number DDD / 1000DH) }\end{array}$ & $\mathbf{7 4 0 , 1 7}$ & $\mathbf{1 6 9 1 , 9 5}$ & $\mathbf{1 6 0 4 , 7 1}$ & $\mathbf{1 1 6 , 8 0 \%}$ & $\mathbf{1 3 4 5 , 6 1}$ \\
\hline $\begin{array}{l}\text { Gynecology sector } \\
\text { (number DDD / 1000DH) }\end{array}$ & $\mathbf{1 3 2 9 , 0 9}$ & $\mathbf{1 1 2 2 , 7 2}$ & $\mathbf{1 3 3 2 , 1 2}$ & $\mathbf{0 , 2 3 \%}$ & $\mathbf{1 2 6 1 , 3 1}$ \\
\hline $\begin{array}{l}\text { Psychiatry sector } \\
\text { (number DDD / 1000H) }\end{array}$ & $\mathbf{8 6 , 6 8}$ & $\mathbf{7 7 , 8 5}$ & $\mathbf{7 3 , 7 9}$ & $\mathbf{- 1 4 , 8 7 \%}$ & $\mathbf{7 9 , 4 4}$ \\
\hline
\end{tabular}

Analysis of average consumption by antibiotic families and by activity sectors

Analysis of the average consumption of antibiotics by families of antibiotics and by sectors of activity has shown that for betalactamins, the gynecology and intensive care sectors are the most prescribing with $1062.12 \mathrm{DDD} / 1000 \mathrm{DH}$ and 943.27 $\mathrm{DDD} / 1000 \mathrm{DH}$ respectively, followed by the surgery sector with $560.74 \mathrm{DDD} / 1000 \mathrm{DH}$ and the medical sector with 447.48 DDD/1000DH. While, ceftazidime and imipenem are essentially prescribed by the resuscitation sector with respectively 26.23 DDD/ $1000 \mathrm{DH}$ and $82.85 \mathrm{DDD} / 1000 \mathrm{DH}$, the surgery sector knows the prescription of these 2 molecules with respectively $9.52 \mathrm{DDD} / 1000 \mathrm{DH}$ and $19.95 \mathrm{DDD} /$
1000DH. For fluoroquinolones, the resuscitation sector is the first prescriber with 114.13 DDD/1000DH, followed by the surgical and medical sectors with 52.96 DDD/1000DH and 46.12 DDD/1000DH respectively. For aminoglycosides, the resuscitation sector is the most prescribing with 106.46 DDD/1000DH, followed by the surgical and medical sectors with respectively $49.43 \mathrm{DDD} / 1000 \mathrm{DH}$ and $41.05 \mathrm{DDD} / 1000 \mathrm{DH}$. For imidazoles, the gynecology sector is the most prescribing with $120.56 \mathrm{DDD} / 1000 \mathrm{DH}$ followed by the resuscitation sector with $73.39 \mathrm{DDD} / 1000 \mathrm{DH}$. For polymyxins (colimycin), the resuscitation sector is the most prescribing with 133.58 DDD/1000DH. For glycopeptides, the resuscitation sector is the most prescribing with 15.91 DDD/1000DH (Table-5).

Table-5: The average consumption by antibiotic families and by activity sectors

\begin{tabular}{|c|c|c|c|c|c|c|}
\hline $\begin{array}{l}\text { ATC } \\
\text { CLASS } \\
\text { ATC }\end{array}$ & Designation & $\begin{array}{l}\text { Average } \\
\text { Medicine }\end{array}$ & $\begin{array}{l}\text { Average } \\
\text { surgery }\end{array}$ & $\begin{array}{l}\text { Average } \\
\text { resuscitation }\end{array}$ & $\begin{array}{l}\text { Average } \\
\text { Gynecology }\end{array}$ & $\begin{array}{l}\text { Average } \\
\text { psychiatry }\end{array}$ \\
\hline J01C & FLUCLOXACILLIN 1G INJ & 21,33 & 41,13 & $\mathbf{3 4 , 8 1}$ & 98,48 & $\mathbf{0 , 0 0}$ \\
\hline J01C & FLUCLOXACILLIN 500 MG CP & 5,73 & 7,11 & $\mathbf{3 , 0 3}$ & $\mathbf{7 , 7 8}$ & 4,48 \\
\hline J01D & AMOXICILLIN 1 G CP & 49,00 & 43,91 & 53,04 & 85,33 & 12,82 \\
\hline J01D & AMOXICILLIN 1 G INJ & 76,04 & 57,65 & 86,63 & 249,96 & $\mathbf{0 , 0 0}$ \\
\hline J01D & $\begin{array}{l}\text { AMOXICILLIN + CLAVULANIC Acid 1G } \\
\text { INJ }\end{array}$ & 137,96 & 151,62 & 200,74 & 266,91 & 0,65 \\
\hline J01D & $\begin{array}{l}\text { AMOXICILLINE + CLAVULANIC Acid } \\
\text { 1G SACHET }\end{array}$ & 87,82 & 148,72 & 135,19 & 343,18 & 54,65 \\
\hline J01D & CEFALOTIN 1G INJ & $\mathbf{0 , 1 5}$ & 15,69 & 44,62 & $\mathbf{0 , 0 0}$ & $\mathbf{0 , 0 0}$ \\
\hline J01D & CEFUROXIM 750 MG INJ & $\mathbf{0 , 0 6}$ & 5,86 & $\mathbf{0 , 7 9}$ & $\mathbf{0 , 0 0}$ & $\mathbf{0 , 0 0}$ \\
\hline J01DD & CEFTAZIDIM 1G INJ & 1,78 & $\mathbf{9 , 5 2}$ & 26,23 & $\mathbf{0 , 0 0}$ & $\mathbf{0 , 0 0}$ \\
\hline J01DD & CEFTRIAXON 1G INJ & 60,42 & $\mathbf{5 9 , 5 8}$ & 212,97 & 9,65 & $\mathbf{0 , 0 0}$ \\
\hline J01DH & IMIPENEM + CILASTATINE 500 MG INJ & 7,19 & 19,95 & 82,85 & $\mathbf{0 , 8 3}$ & $\mathbf{0 , 0 0}$ \\
\hline J01E & $\begin{array}{l}\text { SULFAMETHOXASOLE } \\
\text { TRIMETHOPRIME }\end{array}$ & $\mathbf{0}$ & $\mathbf{0}$ & $\mathbf{0}$ & 0,00 & 0,00 \\
\hline J01F & AZITHROMICINE 500 MG CP & $\mathbf{4 , 7 3}$ & 10,82 & $\mathbf{1 1 , 2 7}$ & 12,63 & $\mathbf{0 , 5 3}$ \\
\hline J01G & GENTAMYCINE 160 MG INJ & 41,05 & 49,43 & 106,46 & 22,72 & $\mathbf{0 , 0 0}$ \\
\hline J01M & CIPROFLOXACINE 200 MG INJ & 20,73 & 18,78 & 107,33 & 2,79 & $\mathbf{0 , 0 0}$ \\
\hline J01M & CIPROFLOXACINE 500 MG CP & 25,39 & $\mathbf{3 4 , 1 8}$ & 16,80 & 40,21 & 2,37 \\
\hline J04AB & RIFAMPICINE & $\mathbf{0}$ & $\mathbf{0}$ & $\mathbf{0}$ & $\mathbf{0 , 0 0}$ & $\mathbf{0 , 0 0}$ \\
\hline J01A & TETRACYCLINE & $\mathbf{0}$ & $\mathbf{0}$ & $\mathbf{0}$ & 0,00 & 0,00 \\
\hline J01X & COLIMYCINE 1 G INJ & 1,03 & $\mathbf{9 , 0 7}$ & 133,58 & $\mathbf{0 , 0 0}$ & 0,00 \\
\hline J01X & VANCOMICINE 500 MG INJ & 2,12 & 1,39 & 15,91 & $\mathbf{0 , 2 8}$ & $\mathbf{0 , 0 0}$ \\
\hline J01X & METRONIDAZOL 500 MG INJ & 18,08 & 39,35 & 70,03 & 95,28 & $\mathbf{0 , 0 0}$ \\
\hline P01AB & METRONIDAZOL 500 MG CP & 8,34 & 10,00 & $\mathbf{3 , 3 6}$ & 25,28 & 3,94 \\
\hline
\end{tabular}




\section{DISCUSSION}

\section{Magnitude of the Problem}

Antibiotics are unique drugs targeting living organisms, they are the only ones whose activity can be questioned over time. Antibiotics are drugs used to treat and prevent bacterial infections. Resistance occurs when bacteria evolve in response to the use of these drugs. Effect explained by the ability of bacteria to gradually acquire resistance to the various antibiotics prescribed and this resistance to antibiotics is only increasing and multi-resistant bacteria are emerging in healthcare services $[1,2]$, making it more difficult to take burden of patients infected with these bacteria. Antibiotic resistance is now dangerously high in all regions of the world. New resistance mechanisms are emerging and spreading worldwide, compromising our ability to treat common infectious diseases. For an increasing number of infections, such as pneumonia, tuberculosis, sepsis and gonorrhea, treatment is becoming more difficult, if not impossible at times, due to the loss of effectiveness of antibiotics. Antibiotic resistance leads to increased medical costs, longer hospital stays and higher mortality. As a result, the prescription of antibiotics remains both in hospitals (strains of MRSA, ESBL enterobacteria) and in the community (strains of pneumococci resistant to penicillin) a public health problem that is difficult to control. There is an urgent need to change the way we prescribe and use these medicines worldwide. Even if new antibiotics are developed, resistance will remain a serious threat without changing behavior. This development must include measures to reduce the spread of infections.

\section{Analysis of the overall consumption of antibiotics in DDD / 1000DH}

For this, our work within the framework of continuous improvement, set itself the goal of a retrospective and descriptive evaluation of the consumption of antibiotics in our establishment to have elements of orientation for our policy of prescriptions of these molecules. In addition, the act of prescribing doctors is limited to a few molecules, often the most recent and / or broad spectrum and mainly used for the treatment of nosocomial infections and / or multidrugresistant bacteria. In our study, the two families most consumed in values are beta-lactams with $77.39 \%$ and fluoroquinolones with $7.21 \%$.

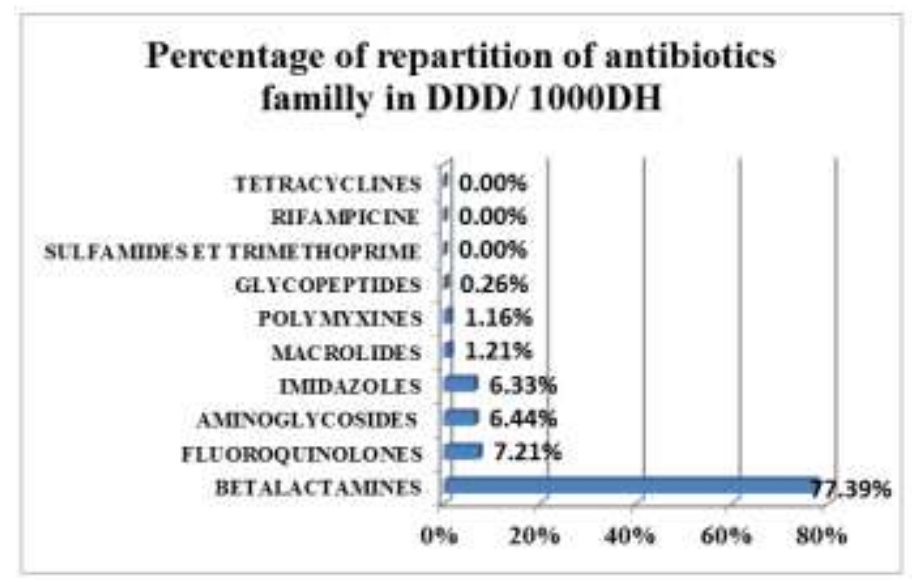

\section{Analysis of the consumption of antibiotics in DDD / $1000 \mathrm{DH}$}

This new indicator makes it possible to include in addition to the number of drugs consumed, the number of beds and the number of hospital days per care unit. It allows a comparison by molecules and by families of antibiotics taking into account a standard dosage (DDD). It also allows easier interpretation by health professionals, by linking the consumption of antibiotics with the number of patients and hospital days. In addition, this indicator makes it possible to carry out annual monitoring of the consumption of antibiotics in the various care services of the same establishment or between health establishments. The use of this indicator has shown that the average overall consumption of antibiotics for all families combined was 777.76 DDD / 1000DH. This level of consumption remains consistent with the data in the literature; who report an overall consumption level varying between 375 DDD / 1000DH for the 2014 Raisin study [3]; of 551.8 DDD / 1000DH the study carried out at the CHU de ROUEN of 2012 [4] at a level of global consumption 1061 DDD / 1000DH for Groote Schuur Hospital (HUGS) in 2012 [5].

\begin{tabular}{|l|l|l|l|l|l|l|l|}
\hline STUDYS & $\begin{array}{l}\text { CHU ROUEN } \\
\mathbf{2 0 1 2}[4]\end{array}$ & $\begin{array}{l}\text { CHU NANTES } \\
\mathbf{2 0 1 0}[7]\end{array}$ & $\begin{array}{l}\text { HMIT } \\
\mathbf{2 0 1 0}[6]\end{array}$ & $\begin{array}{l}\text { ETUDE RAISIN } \\
\mathbf{2 0 1 4}[3]\end{array}$ & $\begin{array}{l}\text { HUGS } \\
\mathbf{1 0 1 2}[5]\end{array}$ & $\begin{array}{l}\text { HUGS } \\
\mathbf{2 0 1 5}[5]\end{array}$ & $\begin{array}{l}\text { study } \\
\text { HMMI }\end{array}$ \\
\hline $\begin{array}{l}\text { Global consumption } \\
\text { (DDD/1000DH) }\end{array}$ & $\mathbf{5 5 1 , 8}$ & $\mathbf{3 9 7 , 9 1}$ & $\mathbf{4 9 9 , 1 4}$ & $\mathbf{3 7 5}$ & $\mathbf{1 0 6 1}$ & $\mathbf{8 6 4}$ & $\mathbf{7 7 7 , 7 6}$ \\
\hline
\end{tabular}


For consumption by business sector; the resuscitation sector comes first with an average overall consumption of $1345.61 \mathrm{DDD} / 1000 \mathrm{DH}$; this result is confirmed by data from the literature; thus the study of the CHU of ROUEN 2012 [4] reported an overall consumption in intensive care of 1352.33 DDD/1000DH and the study Raisin 2014 [3] also reported a total consumption in intensive care of 1468 DDD/1000DH.

\begin{tabular}{|l|l|l|l|}
\hline Activity sectors & $\begin{array}{l}\text { CHU NANTES 2010 [7] } \\
\text { (DDD/1000DH) }\end{array}$ & $\begin{array}{l}\text { ETUDE RAISIN 2014 } \\
\text { [3] (DDD/1000DH) }\end{array}$ & $\begin{array}{l}\text { ETUDE HMMI } \\
\text { (DDD/1000DH) }\end{array}$ \\
\hline Medicine sector & 626,63 & - & 568,96 \\
\hline Surgery sector & 533,12 & - & 733,75 \\
\hline Resuscitation sector & 1352,33 & 1468 & 1345,61 \\
\hline Psychiatry sector & & 61 & 79,44 \\
\hline
\end{tabular}

For consumption by families of antibiotics; penicillins represented by amoxicillin alone or combined with clavulanic acid comes first with 503.17 DDD / 1000DH; followed by cephalosporins and fluoroquinolones and in 2nd row with respectively 65.11 DDD / 1000DH and 56.08 DDD / 1000DH these results are confirmed by the data in the literature $[6,4$, 7].

\begin{tabular}{|l|l|l|l|l|l|}
\hline ATC Class & Antibiotics & $\begin{array}{l}\text { CHU ROUEN 2012 } \\
\text { [4] (DDD/1000DH) }\end{array}$ & $\begin{array}{l}\text { CHU NANTES 2010 } \\
\text { [7] (DDD/1000DH) }\end{array}$ & $\begin{array}{l}\text { HMIT 2010 [6] } \\
\text { (DDD/1000DH) }\end{array}$ & $\begin{array}{l}\text { Study HMMI } \\
\text { (DDD/1000DH) }\end{array}$ \\
\hline J01X-P01AB & imidazoles & 17 & - & 5,13 & 49,23 \\
\hline J01C & penicillins & 312,77 & 215,76 & 180,33 & 503,17 \\
\hline J01M & fluoroquinolons & 47,15 & 43,55 & 72,76 & 56,08 \\
\hline J01DD & cephaloporins & 55,2 & 51,25 & 108,9 & 65,11 \\
\hline J01G & aminoglycosides & 28,1 & 14,6 & 39,46 & 50,12 \\
\hline J01X & glycopeptides & 16,4 & - & - & 2,02 \\
\hline J01DH & carbapenem & 7,49 & - & 27,43 & 15,39 \\
\hline J01F & $\begin{array}{l}\text { macrolides } \\
\text { (azithromycine) }\end{array}$ & 27,26 & 19,81 & 13,18 & 9,41 \\
\hline
\end{tabular}

For the overall consumption of glycopeptides was 2.02 DDD / 1000DH; for carbapenemes this consumption was 15.39 DDD / 1000DH and for polymyxins the consumption was $9.03 \mathrm{DDD} / 1000 \mathrm{DH}$; these results are close to the data in the literature $[6,4$, 7]. The resuscitation sector is the main prescriber of these critical molecules prescribed for nosocomial infections with average consumption for glycopeptides of 15.91 DDD / 1000DH; for carbapenemes with an average consumption of 82.35 DDD / 1000DH and for polymyxins with an average consumption of 133.58 DDD / 1000DH. These results show an important consumption of antibiotics in our hospital training. Thus, the data in the literature have shown that the inappropriate use of antibiotics can lead to the questioning of their activity over time and the appearance of resistant strains, this bacterial resistance compromises the effectiveness of probabilistic antibiotic treatments [8-10]. Various surveys show that 20 to $50 \%$ of antibiotic prescriptions are inappropriate in hospitals [6]. Various studies report that the use of antibiotics for prophylaxis is inappropriate in $40 \%$ to $75 \%$ of cases; whereas $30 \%$ to $75 \%$ of patients with pulmonary infiltrates receive antibiotics for a noninfectious cause [9-11]. The link between the use of antibiotics and the emergence of bacterial resistance is clear: the indiscriminate use of antibiotics promotes the emergence of bacterial resistance [12].
Therefore, the prescription of antibiotics must take into account not only the desired effect on the infection of the treated patients, but also their effects on the bacterial ecology and therefore on the community. It is therefore essential to delay the onset and / or spread of bacterial resistance, and to preserve the activity of antibiotics for as long as possible [2, 12, 13]. To counter this evolution of bacteria, professional recommendations for the proper use of antibiotics, associated with legal provisions, have been put in place in order to optimize the prescriptions of antibiotics, both in extra and intra hospital medicine [2, 12, 13]. The treatment of infections with multi-resistant bacteria reveals economic effects which are linked to the increase in hospital stays, the use of expensive antibiotics to treat them and the burden of care, hence the need raising awareness among all our prescribers of the importance of the act of prescription and its impact on spending on drugs in hospitals $[14,15]$. We would like to update you on the empirical prescriptions of antibiotics of reserves in particular ceftazidime, limipenème, vancomycin and teicoplanin, still active on resistant bacteria, in the majority of care units sometimes can relate to patients not carrying bacteria multi-resistant; this results in overconsumption of this type of antibiotic. 
Our study showed an increase in the consumption of antibiotics with a predominance of consumption of fluoroquinolones known by their great effect in the selection pressure of resistant bacteria - is it an overconsumption? Several studies suggest the existence of an overconsumption of anti-infective products for over-prescriptions, which is justified by multiple reasons $[11,16-18]$ such as, the high number of prescribing doctors; the great diversity of their initial training; lack of knowledge in infectious pathology; the large choice of molecules available; insufficient use of microbiological data; the growing role played by the pharmaceutical industry. The increase in the consumption of antibiotics as well as bad habits in terms of prescription favor the emergence of resistance which is unfortunately in permanent increase with all the financial consequences which results from it [11, $19,20]$.

Thus, the choice of effective antibiotics is made difficult, if not impossible, in certain bacteria infections that are completely resistant to antibiotics. At the same time, the number of antibiotics made available has been increasingly limited in recent years (few new molecules, supply difficulties for old molecules) [12]. Several studies have claimed that antibiotic prescriptions are prone to bad habits and that these prescriptions are far from ideal since 25 to $40 \%$ of hospitalized patients received antibiotics and in 38 to $48 \%$ of these patients this antibiotic therapy was not justified [16-18]. Indeed, the increase in the consumption of antibiotics, which has been objectified in our work within our training, is difficult to interpret; is this abuse of prescriptions or did the antibiotics prescribed really have a clinical or para-clinical justification? However, this situation requires time for reflection in order to set goals for the future [21]. Although the concept of freedom of prescription is defensible by all, good clinical practice therefore requires all practitioners to respect the rules of any prescription to which antibiotic therapy should not be an exception. Knowledge of the indications, dosages, durations of treatment, possible associations and undesirable effects is therefore essential.

The name prescription dated for antibiotics, legibly signed, mentioning the patient's name and the expected duration of treatment, must be generalized $[22,23]$. The computerization of prescription and dispensing becomes essential to ensure traceability and facilitate monitoring of consumption [22, 24]. It is also important to draw up recommendations according to the type of infection; the development of antibiotic reserve lists for certain indications and issued with written justification such as the antibiogram [25].

In the context of curative antibiotic therapy, prescriptions must be limited to infections of bacterial origin documented or probable and for which other measures are not enough, while respecting the dosages and the rhythm of administration, with the choice of antibiotic with the narrowest spectrum, the best diffusion at the site in question, the least toxic, the oldest and the least expensive. While, the use of combinations of antibiotics, aimed at obtaining increased bactericidal activity (synergistic effect) or broadening the antibacterial spectrum (emergency treatment of severe and microbiologically undocumented infections) must be strictly limited to well defined situations.

Whereas for antibiotic prophylaxis, prescriptions must strictly respect the indications and validated regimens and respect for the administrative rules.

\section{CONCLUSION}

At the end of our work, an evaluation of the consumption of antibiotics, the results of which revealed a significant consumption of antibiotics in our hospital. The comparison of our results with data from the literature and with the results of other hospital structures at international level, allowed us to position the consumption of our structure and thus to develop reviews and to propose corrective measures for the improvement of their prescriptions. In light of these results, an awareness of the seriousness of misuse of antibiotics is essential if we want to preserve the rare antibiotics that remain, and protect the rare ones that will appear. Thus, we deem it necessary to disseminate our results to all prescribers in our hospital and especially to encourage all "doctors, microbiologists and pharmacists" to collaborate in the implementation of antibiotic therapy protocols within the framework of the committee. Fight against nosocomial infections and the antibiotics sub-committee with the aim of adopting a policy of good use of antibiotics; while taking into account our bacterial ecology by comparing it with the data in the literature to better control the occurrence of bacterial resistance and minimize the economic consequences of the emergence of multidrug-resistant bacteria.

\section{REFERENCES}

1. Conférence d'experts organisée par la société française d'anesthésie réanimation. Antibioprophylaxie probabiliste des états septiques graves. 14 Septembrer 2004.

2. Carlet, J., Rambaud, C., \& Pulcini, C. (2012). Alliance contre les bacteries multiresistantes: sauvons les antibiotiques. Annales Françaises d'Anesthesie et de Reanimation. 31:704-708.

3. Péfau, A. M. R., Schlemmer, B., Sénéchal, H., \& Touratier13, S. (2016). Surveillance des consommations d'antibiotiques: une étape clé dans la lutte contre l'antibiorésistance Les apports du réseau ATB-Raisin. Bulletin CClin-Arlin $n$. 
4. Durand, A. L. (2014). Analyse des consommations antibiotiques et des résistances bactériennes dans huit établissements de santé de Haute-Normandie.

5. Boyles, T. H., Naicker, V., Rawoot, N., Raubenheimer, P. J., Eick, B., \& Mendelson, M . (2017). Sustained Reduction in Antibiotic Consumption in a South African Public Sector Hospital; Four Year Outcomes from the Groote Schuur Hospital Antibiotic Stewardship Program. $S$ Afr Med J. 30;107(2):115-118.

6. Jaouadi, T., Aouida, N., Jenane, F., Asli, M. S., Dridi, M., Yousfi, M. A., \& Barguellil, F. Evolution de la consommation des antibiotiques à l'hopital Militaire principal d'instruction de Tunis entre 2008 et 2010 https://www.researchgate.net/publication/2743883 00

7. Hamon, M. (2012). Mise en place d'un observatoire de consommation d'antibiotiques à l'échelle de l'unité fonctionnelle au CHU de Nantes (Doctoral dissertation, Thèse de doctorat en médecine, Sous la direction de Pr Françoise BALLEREAU, Nantes, 2012, 120p).

8. Veber, B. (2008). Conduite de l'antibiothérapie probabiliste. Le Praticien en anesthésie réanimation, 12(2), 78-84.

9. Carod, J. F., Floret, N., Draou, B., Daucourt, V., Sakho, A., Blanc, E., ... \& Leroy, J. (2013). Analyse rétrospective de l'antibiothérapie probabiliste des infections respiratoires basses chez des patients admis aux urgences du centre hospitalier Louis-Jaillon (Saint-Claude, France). Journal Européen des Urgences et de Réanimation, 25(3-4), 141-146.

10. Asseray, N., Bleher, Y., Poirier, Y., Hoff, J., Boutoille, D., Bretonniere, C., Lombrail, P., \& Potel. G. (2009). L'antibiothérapie aux urgences, évaluation par une approche qualitative et quantitative. Médecine et maladies infectieuses. 39:203-208.

11. Badiaga, S., \& Gerbeaux, P. (2006). Antibiothérapie aux urgences. Réanimation, 15(78), 514-522.

12. Libellé, A. (2008). Stratégie d'antibiothérapie et prévention des résistances bactériennes en établissement de santé. In Annales Françaises d'Anesthésie et de Réanimation (Vol. 27, pp. 772788).

13. Jean-Verdier, C. H. U. (2004). Guide bon usage des antibiotiques aux urgences; 2.

14. Chaix, C., Durant-Zalesski, I., \& Brun-Buisson, C. (1996). Impact économique des infections nosocomiales : le cas de la multirésistance bactérienne. In: XVI Conférence de Consensus en réanimation et médecine d'urgence. Prévention des infections à bactéries multirésistantes en réanimation. Villejuif: SRLF.

15. Thomas, R., Canus, C. (1996). La multirésistance augmente t-elle la fréquence et la gravité (morbidité et mortalité) des infections nosocomiales? In: XVI Conférence de, consensus en réanimation et médecine d'urgence. Prévention des infections à bactéries multi-résistantes en réanimation. Ville juif: SRLF.

16. 14ème conférence de consensus organisée par la société de pathologie infectieuse de langue française. Comment améliorer la qualité de l'antibiothérapie dans les établissements de soins. Paris; 6 Mar; 2002.

17. Badiaga, S., \& Gerbeaux, P. (2006). Antibiothérapie des urgences. Réanimation. 15:514-522.

18. Monnet, D. L. (2000). Consommation d'antibiotiques et résistance bactérienne. Ann $\mathrm{Fr}$ Anesth Réanim. 19:409-417

19. McGowan, J. E. (1983). Antimicrobial resistance in hospital organismsand its relation to the antibiotic use. Rev Infect Dis. 5:1033-1048.

20. Cooke, D. M., Salter, A. J., \& Phillips, I. (1980). Antimicrobial misuse, antibiotic policies and information resources. J Antimicrob Chemother. $6: 435-443$.

21. Henard, S., Rahib, D., Léon, L., Amadéo, B., Dumartin, C., Cavalié, P., \& Coignard, B. (2011). Consommation des antibiotiques rapportée via les bilans standardisés de lutte contre les infections nosocomiales et relation avec l'ICATB. Médecine et maladies infectieuses. 41:197-205.

22. 14e Conférence de Consensus organisé par la Société de Pathologie Infectieuse de Langue Française. Comment améliorer la qualité de l'antibiothérapie dans les établissements de soins. Qualité = préserver l'intérêt collectif sans nuire à l'intérêt individuel du patient. Du 6 mars Institut Pasteur - Paris, soutien institutionnel de (AFSSAPS et InVS).

23. Esposito, G., \& Castel, O. (2010). Évaluation sur 2006 et 2007 de la politique de bon usage des antibiotiques dans les établissements de santé de la région Poitou-Charentes. Médecine et maladies infectieuses. 40:31-37.

24. Agence Nationale pour Développement de l'Evaluation en Santé (ANAES) Le bon usage des antibiotiques à l'hôpital, dans l'optique d'une démarche qualité et d'une maîtrise du développement de la résistance bactérienne, Août 1996.

25. Denes, E., \& Bergogne-Bérézin, E. (2008). Les bases de l'antibiothérapie aujourd'hui : diagnostics rapides, nouvelles méthodes, innovations. Antibiotiques. 10 :128-133. 